\title{
Use of the Learning Management System (LMS) at the Instituto Tecnológico de Oaxaca
}

\section{Uso del Sistema de Gestión del Aprendizaje (LMS) en el Instituto Tecnológico de Oaxaca}

\author{
DÍAZ-SARMIENTO, Bibiana†*, SÁNCHEZ-JIMÉNEZ, Daniel Antonio, MORALES-HERNÁNDEZ, \\ Maricela and RAFAEL-PÉREZ, Eva
}

Tecnológico Nacional de México - Instituto Tecnológico de Oaxaca, Departamento de Sistemas y Computación, Avenida Ing. Victor Bravo Ahuja No. 125 Esquina Calzada Tecnológico, C.P. 68030, México.

\author{
ID $1^{\text {st }}$ Author: Bibiana, Díaz-Sarmiento / ORC ID: 0000-0003-4350-6311, CVU CONACYT ID: 820776 \\ ID $1^{\text {st }}$ Co-author: Daniel Antonio, Sánchez-Jiménez / ORC ID: 0000-0003-4386-8291, CVU CONACYT ID: 1148683 \\ ID $2^{\text {nd }}$ Co-author: Maricela, Morales-Hernández / ORC ID: 0000-0002-3521-2041, CVU CONACYT ID: 731036 \\ ID $3^{\text {rd }}$ Co-author: Eva, Rafael-Pérez / ORC ID: 0000-0003-2793-1254, CVU CONACYT ID: 905268
}

DOI: $10.35429 / J C S I .2021 .19 .7 .30 .36$

Received July 30, 2021; Accepted October 28, 2021

\begin{abstract}
Educational platforms are tools that facilitate the teaching learning process. The LMS platforms: Edmodo, Schollogy and Moodle complement this process between students and professors. The use of these platforms was analyzed at the Technological Institute of Oaxaca, with the participation of students from the following careers: Electronic Engineer, Electrical Engineer, Civil Engineer, Mechanical Engineer, Industrial Engineer, Chemical Engineer, Business Management Engineer, Computer Systems Engineer, Bachelor of Administration and professors; all of them agree with that the most used platform is Moodle. One of the main objective is identify and classify the LMS used by students of the semesters: second, fourth, sixth, eighth and tenth, as well as teachers during the period January-June 2019. In addition, it was analyzed the use of LMS and the percentage of students and professors who use the platform as a teaching-learning strategy is determined. For the analysis of the use of LMS in the Technological Institute of Oaxaca, the methodology that was considered consists in the next phases: problem statement, definition of objective, elaboration of the theoretical framework, elaboration and analysis of surveys, process design and conclusions.
\end{abstract}

LMS, Moodle, Platforms

\begin{abstract}
Resumen
Las plataformas educativas son herramientas que facilitan el proceso de enseñanza aprendizaje. Las plataformas LMS: Edmodo, Schollogy y Moodle complementan este proceso entre estudiantes y docentes. El uso de estas plataformas fue analizado en el Instituto Tecnológico de Oaxaca, con la participación de estudiantes de las carreras: Ing. Electrónica, Ing. Eléctrica, Ing. Civil, Ing. Mecánica, Ing. Industrial, Ing. Química, Ing. en Gestión Empresarial, Ing. en Sistemas Computacionales, Lic. en Administración y docentes, coincidiendo que la plataforma más utilizada es Moodle. En los objetivos se identifican y clasifican los LMS utilizados por estudiantes de los semestres: segundo, cuarto, sexto, octavo y décimo, así como docentes durante el período enero-junio del 2019. Se analiza el uso de LMS, se determina el porcentaje de estudiantes y docentes que utilizan la plataforma como estrategia de enseñanza aprendizaje. Para el análisis del uso de LMS en el Instituto Tecnológico de Oaxaca se considero la metodología en sus diferentes fases: planteamiento del problema, definición de objetivo, elaboración del marco teórico, elaboración y análisis de encuestas, diseño de procesos y conclusiones.
\end{abstract}

LMS, Moodle, Plataforma

Citation: DÍAZ-SARMIENTO, Bibiana, SÁNCHEZ-JIMÉNEZ, Daniel Antonio, MORALES-HERNÁNDEZ, Maricela and RAFAEL-PÉREZ, Eva. Use of the Learning Management System (LMS) at the Instituto Tecnológico de Oaxaca. Journal of Computational Systems and ICTs. 2021. 7-19: 30-36

\footnotetext{
$\dagger$ Researcher contributing as first Author.
} 


\section{Introduction}

The TIC are a great impact on world education, specifically in the educational field, the use at the Higher Education level contributes to the constant updating of pedagogical practices, with the inclusion of innovative, flexible and dynamic methods, creating a new educational environment. (Ulloa, 2018).

The LMS (Learning Management Systems - Sistema de Gestión de Aprendizaje) They are course containers that incorporate communication and monitoring resources for the student and the teacher (Mendoza 2016). It is important to know the main factors for the use of platforms, the diversity offered by the network and the characteristics between one and another.

In 2019 in the Instituto Tecnológico de Oaxaca (ITO), Educational platforms were used to offer courses or diplomat for teachers, on the other hand, some teachers used LMS platforms when teaching their classes, however, it was not mandatory to work with them. Based on the study carried out, the Moodle platform was recognized as the most used among students and teachers.

This work reflects the usability analysis of the platforms LMS: Edmodo, Schollogy and Moodle in teachers and students register in the nine careers, during the period January-June 2019. The hypothesis to be demonstrated is: The low usability of the LMS platforms (Moodle, Schollogy and Edmodo) by ITO students and teachers, allows the creation and proposal of the process for good practices. Because of that, this work covers the following topics: Problem Statement, Theoretical Framework, Development Methodology, Preparation of surveys, Results of surveys, Conclusions, Acknowledgments and References.

\section{Problem statement}

Pineda, 2003 cites that TIC are the means to generate knowledge and facilitate entry to the accumulation of information that is available today with the use of the network. In Higher Education Institutions, the use of distance learning techniques (online) is more and more frequent, in some institutions, this learning has completely replaced the classic courses (Umek et al., 2015).
The ITO in the year 2017 registers an enrollment of 6,840 students enrolled in the careers: Industrial Engineer, Electrical Engineer, Electronic Engineer, Computer Systems Engineer, Chemical Engineer, Mechanical Engineer, Civil Engineer, Engineer in Business Management and Bachelor of Administration, at that time, 253 workers have teaching positions. Being a Higher Education Institution in continuous improvement, it incorporates the use of Moodle as a teaching-learning strategy.

In contrast, the population that uses LMS platforms is unknown, however, information collected from the Computer Center tells us that: $100 \%$ of the population has access to the internet, officially since 2008 the Moodle platform has been used, the careers they use most frequently are: Industrial Engineer, Chemical Engineer and Computer Systems Engineer. The total number of teachers and students using Moodle is ignored. On the other hand, there is an initiative to increase the use of Moodle through the inter-monthly courses offered in the months of January and August of each year.

The LMS allow the student to have access to the virtual classroom and course content at any time. For teachers it is allowed to create a virtual classroom, organize the course using tools such as: control, monitoring, continuous evaluation, flexibility and effectiveness.

\section{Theoretical framework}

One of the characteristics of LMS Moodle is that it is based on a constructivist approach to learning, where students and teachers contribute to the educational experience in various ways. (Clarenc 2013).

In accordance with Enriquez L. (2004), "the platforms" or Learning Management System (LMS) are characterized by creating learning environments based on tools such as:

$\begin{array}{ll}- & \text { Course Catalog } \\ - & \text { Registration system } \\ - & \text { Self-assessment mechanisms } \\ - & \text { Monitoring of student performance } \\ - & \text { Digital libraries } \\ - & \text { Statistics and information on courses and } \\ & \text { students }\end{array}$


- Support for learning communities, among others.

Clarenc (2013) cites that there are eight characteristics that E-learning platforms must meet:

$\begin{array}{ll}- & \text { Interactivity } \\ - & \text { Flexibility } \\ - & \text { Scalability } \\ - & \text { Standardization } \\ - & \text { Usability } \\ - & \text { Functionality } \\ - & \text { Ubiquity } \\ - & \text { Persuability }\end{array}$

\section{LMS Moodle}

Ramírez (2010) states that Moodle is a Resource Management System, an online tool for teachers that allows you to create dynamic Web sites for your students. It has tools to create online learning communities where there is continuous (virtual) communication. Figure 1 shows the Moodle - ITO platform.

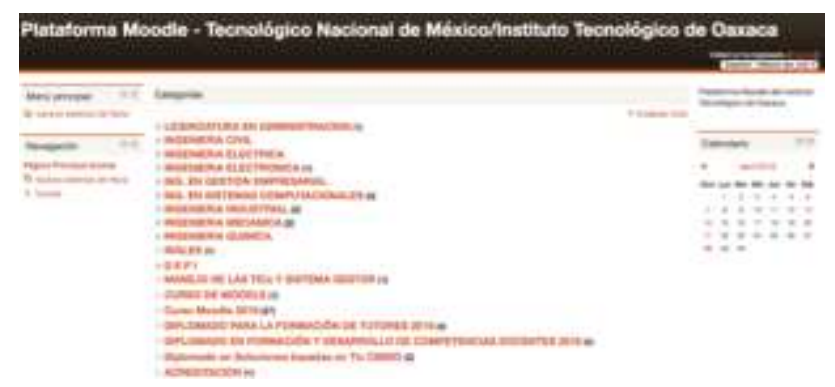

Figure 1 Moodle - ITO platform

Source: http://moodle.itoaxaca.edu.mx

Based on ANUIES (2018) in the study: "Current state of Information and Communication Technologies in Higher Education" 144 institutions were surveyed. The product used by Higher Education Institutions as a Virtual Learning platform is $77 \%$, where 3 out of 4 HEIs surveyed use MOODLE as a Virtual Learning Platform.

\section{LMS Schollogy}

Ocampo (2014) cites that the educational platform Schollogy offers tools necessary to manage an online classroom, through an interface similar to a social network. This platform offers services such as: managing courses, students, resources, activities, discussion forums, etc.
It also has a mobile application that allows the student and teacher to operate the platform from a mobile device. The Schollogy platform is shown in Figure 2.

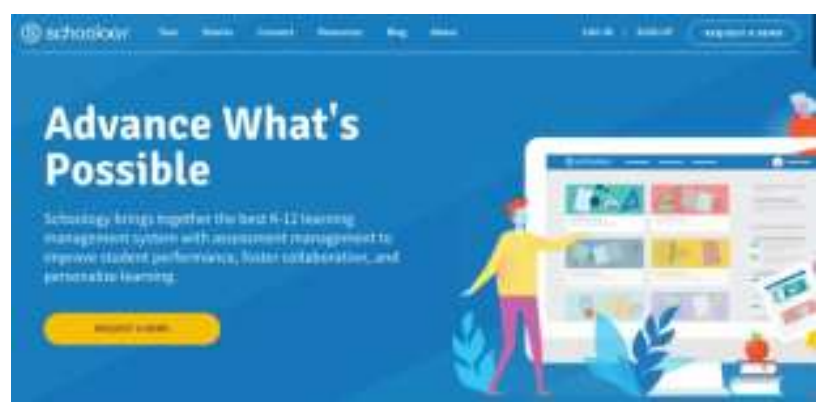

Figure 2 LMS Schollogy platform

Source: https://www.schoology.com/

\section{LMS Edmodo}

López, Flores \& González (2012) mention that Edmodo is one of the social learning platforms and without cost, safe for students, teachers and families. Groups, data and assignments are created in it in a structured way. Figure 3 shows the Edmodo platform.

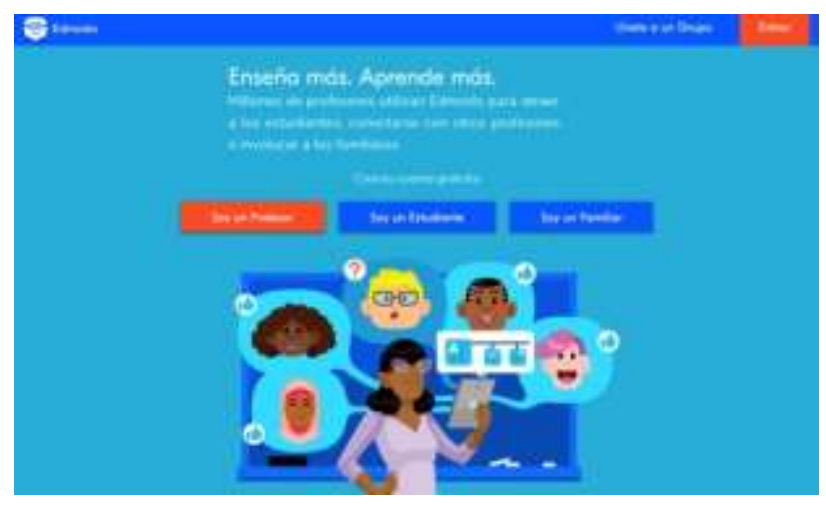

Figure 3 Edmodo LMS platform Source: https://www.edmodo.com/

Other examples of LMS platforms are:

$\begin{array}{ll}- & \text { Canvas LMS } \\ - & \text { Chamilo LMS } \\ - & \text { Sakai } \\ - & \text { eDucativa } \\ - & \text { Google Classroom } \\ - & \text { Neo LMS }\end{array}$

\section{Usability}

It has to do with the way an element is used (tool, electronic device, program, interface, etc.), it is the ease of using it, allowing it to do what is needed. Software usability is the ease for users to use a software application. (Enríquez, 2014). 
Nielsen (1992) mentions that usability has five attributes:

- $\quad$ Ease of learning. Identify how easy it is to learn the basic functionality of the system.

- $\quad$ Efficiency. Seeks the maximum speed of completion of user tasks.

- $\quad$ Remember in time. It is essential to use the system without the need to learn its operation from scratch each time.

- $\quad$ Error rate. It is the number of errors made by the user while performing a certain task.

- Satisfaction. It is the subjective impression that the user has of the system.

\section{Development methodology}

The research method was field because information about the object of study was collected, processed and analyzed, in this case being two objects: students and teachers. The methodology used was from Hernández (2010) with adjustments resulting in Figure 4.

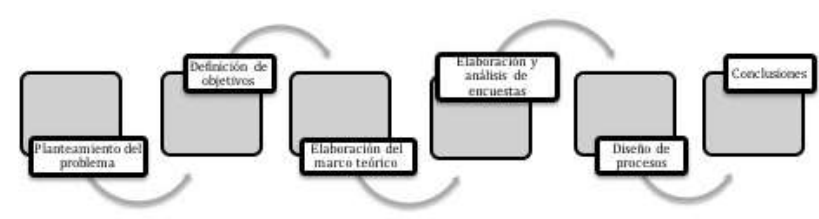

Figure 4 Phases of methodology

Source: Metodología de la investigación (Sampieri,2010)

Problem statement: In this phase, the LMS platforms used in the ITO, the areas or departments involved in their use, are analyzed. Definition of objectives: General and specific objectives of the research are established, among them is to identify, classify and analyze the use of LMS used by ITO students and teachers. Elaboration of the theoretical framework: The definition of LMS and characteristics are taken into account. The Moodle, Schollogy and Edmodo platforms, advantages, disadvantages and common aspects were analyzed. Preparation and analysis of surveys: Surveys were applied to teachers and students of the ITO to identify which platform is the most used, usability of said platforms, which personnel use the platforms the most and why. Process design: The proposal is designed through a procedure to increase the usability of the LMS Moodle platform.
The research was carried out with students and teachers from the January-June 2019 school semester, a random sample of $5 \%$ of a total of 6,000 students was considered; for the case of teachers out of a total of 253, the random sample of 5\% was considered. During the design of the research, information was collected from students and teachers through a survey considering the variables: LMS and usability. To prepare the survey, demographic data were considered: position (student, teacher), sex, age, enrolled semester, department of assignment, schooling and profession.

The operationalization of the variables was also carried out, Figure 5.

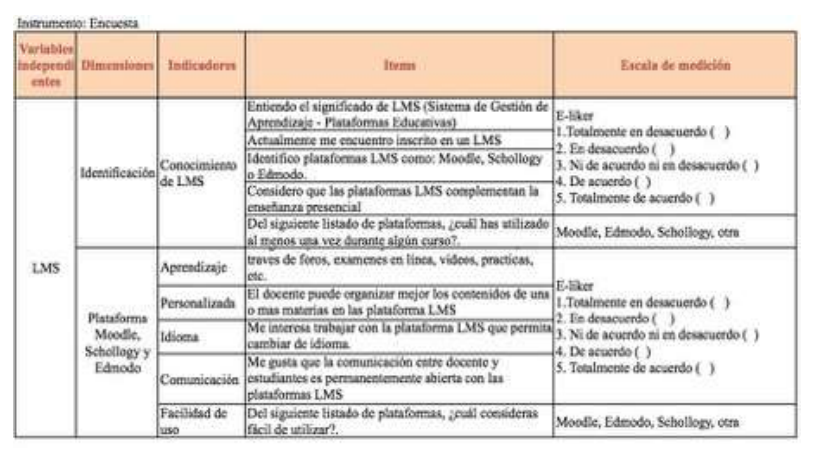

Figure 5 Operationalization of variables

Source: Own elaboration

\section{Preparation of surveys}

Two main pages were analyzed for the survey management Survey Monkey® and Google Forms, Figure 6 shows the characteristics of the two applications..

\begin{tabular}{|c|c|c|c|c|l|}
\hline Aplicación & Gratuita & Planes & $\begin{array}{c}\text { No. } \\
\text { preguntas }\end{array}$ & $\begin{array}{c}\text { No. } \\
\text { respuestas }\end{array}$ & $\begin{array}{l}\text { Tipos de } \\
\text { preguntas }\end{array}$ \\
\hline SuverMonkey & No & $\begin{array}{l}\text { Estándar } \\
\text { Avanzado }\end{array}$ & $\begin{array}{l}\text { Ilimitado } \\
\text { para cada } \\
\text { tipo de plan }\end{array}$ & $\begin{array}{l}\text { llimitado } \\
\text { para cada } \\
\text { tipo de } \\
\text { plan }\end{array}$ & $\begin{array}{l}15 \text { tipos } \\
\text { de } \\
\text { preguntas } \\
\text { diferentes }\end{array}$ \\
\hline Google Forms & Si & Ninguno & Ilimitado & Ilimitado & $\begin{array}{l}9 \text { tipos de } \\
\text { preguntas } \\
\text { diferentes }\end{array}$ \\
\hline
\end{tabular}

Figure 6 Operationalization of variables Source: Own Elaboration

To carry out the surveys to students and teachers, Google Forms was used with an academic account. 


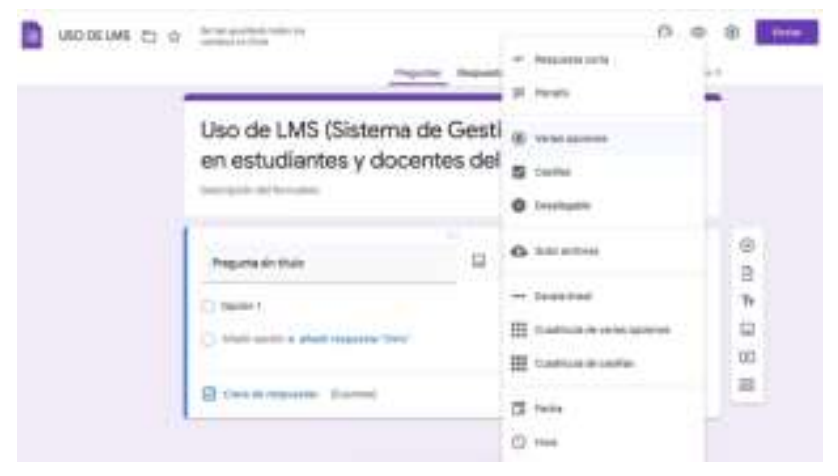

Figure 7 Survey design

Source: Own Elaboration

Some questions from the survey were:

I identify LMS platforms such as: Moodle, Schollogy or Edmodo.

Strongly disagree

In disagreement

Neither agree nor disagree

Agree

Totally agree

I believe that LMS platforms complement faceto-face teaching.

Strongly disagree

In disagreement

Neither agree nor disagree

Agree

Totally agree

I like to learn on the LMS Moodle platform, through forums, online exams, videos, practices, etc.

Strongly disagree

In disagreement

Neither agree nor disagree

Agree

Totally agree

The teacher can better organize the contents of one or more subjects in the LMS platforms.

Strongly disagree

In disagreement

Neither agree nor disagree

Agree

Totally agree

On the other hand, with the IBM SPSS program the Descriptive Statistical Analysis of Frequencies was carried out, generating bar and sector graphs.

\section{Survey results}

The time that teachers and students spend connected to the Internet is 3 to 4 hours as shown in Figure 8.

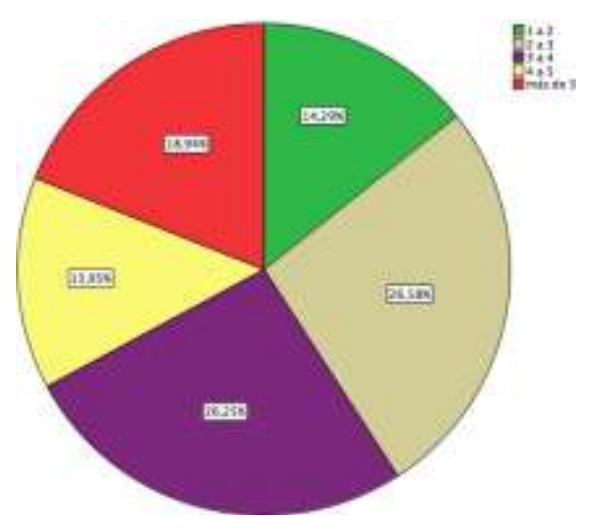

Figure 8 Daily hours connected to the internet Source: Own Elaboration

Of the teachers and students surveyed, $75 \%$ are not currently enrolled in an LMS, as shown in Figure 9.

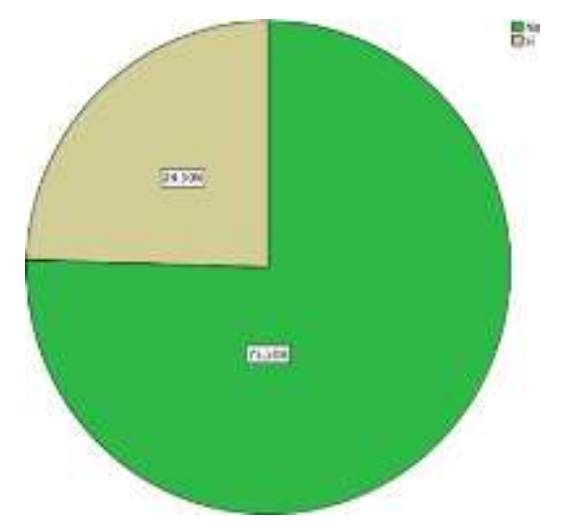

Figure 9 Registered in platform LMS

Source: Own Elaboration

Figure 10 shows the platforms that were used at least once during a certain course, with Moodle predominant with $62 \%$ followed by Edmodo with 27\% and Schollogy with $8 \%$.

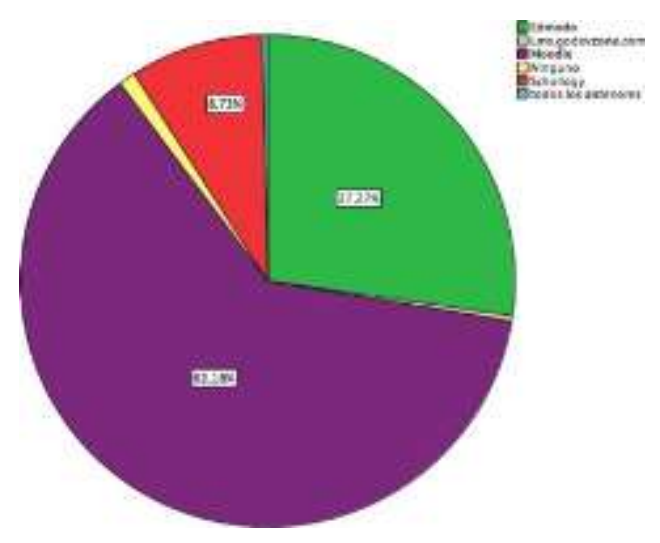

Figure 10 Platforms used at least once in a course Source: Own Elaboration

DÍAZ-SARMIENTO, Bibiana, SÁNCHEZ-JIMÉNEZ, Daniel Antonio, MORALES-HERNÁNDEZ, Maricela and RAFAEL-PÉREZ, Eva. Use of the Learning Management System (LMS) at the Instituto Tecnológico de Oaxaca. Journal of Computational Systems and ICTs. 2021 
Regarding the ease of use of the platforms, the results of the surveys indicate that Moodle is easier to use with $56 \%$, followed by Edmodo with $34 \%$ and Schollogy with $8 \%$ as indicated in Figure 11.

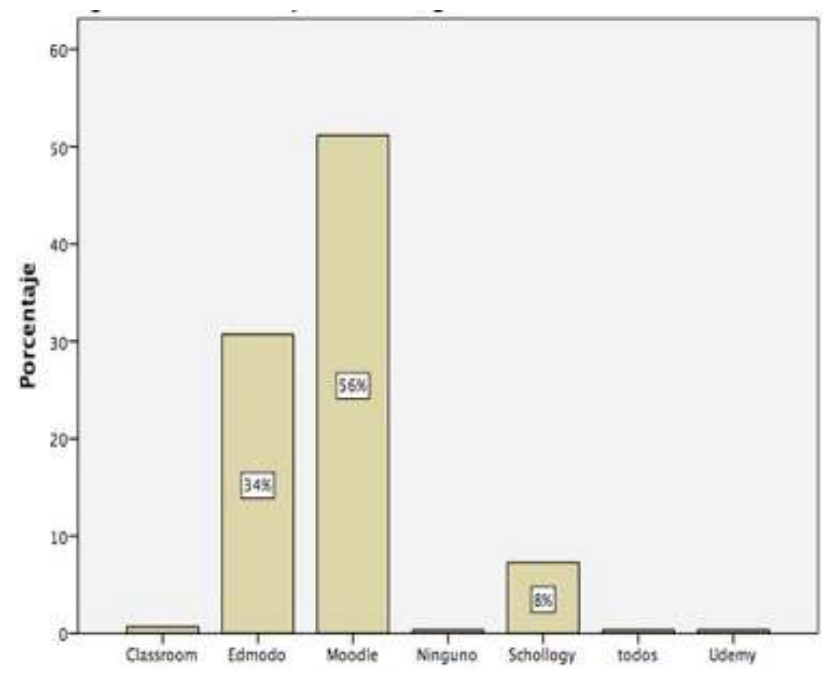

Figure 11 Easy to platforms

Source: Own Elaboration

For good practices in the Use of LMS, the process in Figure 12 was developed for the use of LMS platforms.

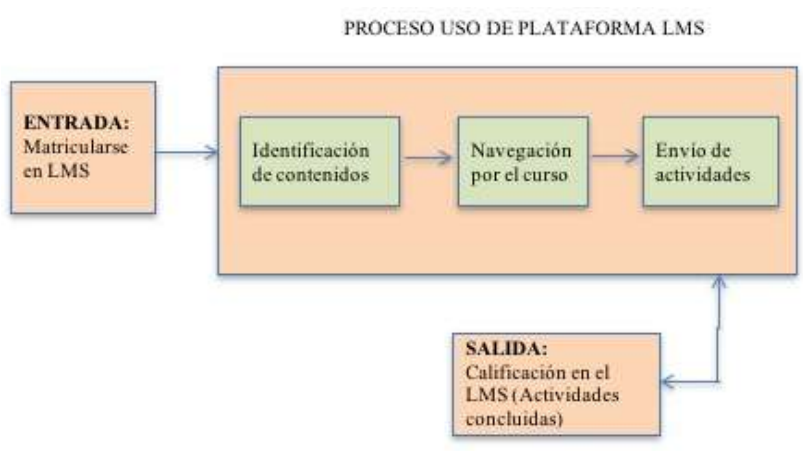

Figure 12 LMS use platform process

Source: Own Elaboration

\section{Acknowledgment}

To the Tecnológico Nacional de México, Instituto Tecnológico de Oaxaca.

Our recognition to the departments that supported us during the time of the investigation:

General direction Instituto Tecnológico de Oaxaca.

\section{Computer Center Department.}

Systems and Computing Department.
For all the facilities to be able to collect the information in a timely manner.

Also the recognition to the ITO students of the different careers, who gave themselves the time and space to respond to the survey, to the teachers assigned to the different academic departments who in the same way contributed by answering with or without the experience in the use of LMS platforms.

\section{Conclusions}

The transformations in school education are changing the relationship between the teacher who teaches, the students who learn and the contents that are the object of teaching and learning, configuring new spaces and educational scenarios that are increasingly influential and decisive in the processes of development and socialization, forcing a critical review of the functions and purposes of education.

During this transformation, educational platforms emerge that support the student to learn in a constructivist way. In this sense, this research reflected the analysis of Moodle, Edmodo and Schollogy Learning Management System (LMS) platforms.

In the research, it was detected that $85.33 \%$ of the respondents have a desktop or laptop with an Internet connection and the number of hours per day that ITO students and teachers spent connected to the Internet is two to three hours, which would not be a limitation to use LMS platforms. On the other hand, it was detected that there is low knowledge of the platforms, the ITO has used the LMS Moodle platform since 2008 , but only $15 \%$ of teachers use it with their students.

The LMS used by students and teachers of the TecNM campus Instituto Tecnológico de Oaxaca were identified and classified, the percentage that use said ICT as a teachinglearning strategy was analyzed and determined.

This research tests the theory of constructivism where students and teachers build their own knowledge and its meaning from access to LMS platforms. 
The information collected in the survey applied to students and teachers of the TecNM campus Instituto Tecnológico de Oaxaca is protected in accordance with the Federal Law on Protection of Personal Data Held by Private Parties (LFPDPPP).

Currently, the use of the LMS Moodle platform has increased by more than $50 \%$, from 1 to 5 courses were created for each teacher, students from different careers entered to carry out the different activities requested. It is worth mentioning that at the same time three diplomas are offered for teachers through the Moodle platform.

During the health contingency due to coronavirus COVID-19, 800 courses (groups) were created on the LMS Moodle platform to be used by students and teachers.

\section{References}

ANUIES (2018). Asociación Nacional de Universidades e Instituciones de Educación Superior. Estado Actual de las Tecnologías de la Información y las Comunicaciones en las Instituciones de Educación Superior en México. Estudio 2018.

Clarenc, C. A.; S. M. Castro, C. López de Lenz, M. E. Moreno y N. B. Tosco (diciembre, 2013). Analizamos 19 plataformas de eLearning: Investigación colaborativa sobre LMS. Grupo GEIPITE, Congreso Virtual Mundial de ELearning.

Clarenc, C. A. (2013, octubre). Instrumento de evaluación y selección de sistemas de gestión de aprendizaje y otros materiales digitales. Medición y ponderación de LMS y CLMS, recursos educativos digitales y herramientas o sitios de la WEB 3.0. Congreso Virtual Mundial de E-Learning, Grupo GEIPITE.

Enríquez, J.G., \& Casas, S. I. (2014). Usabilidad en aplicaciones móviles. Informes Científicos Técnicos - UNPA, 5(2), 25-47.

Hernández Sampieri, Roberto, Fernández Collado, Carlos \& Baptista Lucio, María del Pilar (2010). Metodología de la Investigación, $5^{\text {a }}$ edición. Editorial McGraw-Hill
López, J. M. S., Flores, M. F., \& González, J. L. G. (2012). Descubriendo Edmodo: beneficios del microblogging en educación en adultos. Campo abierto: Revista de educación, 31(2), 5370.

Mendoza, L. V. (2016). Schoology \& Media Scape: una combinación exitosa para apoyar el aprendizaje mediado por tecnología.

Nielsen, J (1993). Usability Engineering. AP Professional.

Ocampo, M. A. L. (2014). Experiencia en el uso de la Plataforma Schoology como estrategia de acompañamiento docente en los cursos de Ciencias Básicas de la Universidad Católica Luis Amigo (FUNLAM). La Investigación, 1, 383.

Pineda, M. E. D. (2003). La sociedad de la información como una sociedad en transición: Caracterización, tendencias y paradojas. Revista de Ciencias Sociales (RCS), IX (2), 252- 270.

Ramírez Salazar, Adriana Natalia (2010). Sistema de entrenamiento virtual basado en Web usando componentes de software (Tesis maestría). Instituto Politécnico Nacional. Centro de Investigación en Computación.

Ulloa-Duque, G. S., Hernández-Moreno, L. A., \& Tovar-Morales, M. T. (2018) Incursión de la herramienta Schoology en la asignatura de Matemáticas Financieras.

Umek, L., A. Aristovnik, N. Tomazevic y D. Kerzic, Analysis of Selected Aspects of Students' Performance and Satisfaction in a Moodle-Based E-Learning System Environment. 